https://doi.org/10.52058/2786-4952 -2021-4(4)-353-364

Заболоцький Назар Дмитрович студент Інституту прокуратури та кримінальної юстиції, Національний юридичний університет імені Ярослава Мудрого, вул. Пушкінська, 106, м. Харків, 02000, тел.: (068) 086-68-64, e-mail: n.d.zabolotskyy@nlu.edu.ua, https://orcid.org/0000-0002-6077-8514

Заболоцька Світлана Ігорівна кандидат психологічних наук, доцент кафедри психології, Дрогобицький державний педагогічний університет імені Івана Франка, вул. І. Франка, 24, м. Дрогобич, 27100, тел.: (097) 029-82-48 , e-mail: svitlana.zabolotska@ukr.net, https://orcid.org/0000-0003-0686-7185

Заміщак Марія Ігорівна кандидат психологічних наук, доцент кафедри психології, Дрогобицький державний педагогічний університет імені Івана Франка, вул. І. Франка, 24, м. Дрогобич, 27100, тел.: (0980 418-72-43, e-mail: dpszammeri@gmail.com, https://orcid.org/0000-0003-4559-1257

\title{
ПСИХОЛОГІЧНІ ЧИННИКИ СТАНОВЛЕННЯ ПРОФЕСІЙНОЇ Я-КОНЦЕПЦІї У МАЙБУТНІХ ФАХІВЦІВ
}

Анотація. У статті аналізується Я-концепція, яка являє собою сукупність всіх уявлень індивіда про себе і включає переконання, оцінки і тенденції поведінки.

Розрізняють позитивну і негативну Я-концепцію. Зазначається, що кожна людина хоче досягнути максимальної внутрішньої гармонії. Уявлення, почуття або ідеї, що вступають в суперечність з іншими іiі уявленнями, почуттями або ідеями призводять до дисгармонізації особистості, до ситуації психологічного дискомфорту.

Проведено аналіз професійного становлення майбутнього фахівця. Констатується, що професійне становлення майбутнього фахівця - складний, неперервний процес "проектування” особистості.

Акцентовано, що студент, як майбутній професіонал, який прагне досягти високої професійної культури, необхідні постійний самоаналіз, усвідомлення власних дій та вчинків, самоспостереження, здатність вести безперервний внутрішній діалог. Таке самоспілкування $\epsilon$ основою професійного самовдосконалення, оскільки дає можливість коригувати власні недоліки, розвивати необхідні для професії здібності та якості.

Підкреслено, що самооцінка виконує роль підгрунтя, на якому будується вся цілеспрямована діяльність особистості, і яка в значній мірі визначає результат цієї діяльності. Від умов самооцінювання залежить активність особистості 
майбутнього фахівця, іiі участь у професійній діяльності, iї прагнення і вміння оцінювати свої інтереси. Зазначено, що професіоналізм майбутнього фахівця потребує формування власної позитивної Я-концепції.

Виділено психологічні чинники становлення професійної Я-Концепції у майбутніх фахівців. Стверджується, що психологічні чинники, якості, які повинні бути притаманні особистості майбутнього фахівця будуть основою позитивної Я-концепції.

Ключові слова: психологічні чинники, майбутні фахівці, Я-концепція, професійне становлення, професіоналізація, заклад вищої освіти.

Zabolotskyi Nazar Dmytrovych Student of the Institute of Prosecutor's Office and Criminal Justice of Yaroslav Mudryi National Law University, Pushkinska St., 106, Kharkiv, 02000, tel.: (068) 086-68-64, e-mail: ndzabolotskyy@nlu.edu.ua, https://orcid.org /0000-0002-6077-8514

Zabolotska Svitlana Ihorivna Candidate of Psychological Sciences, Associate Professor of the Department of Psychology, Drohobych Ivan Franko State Pedagogical University, I. Franko St., 24, Drohobych, 27100, tel.: (097) 029-82-48, email: svitlana.zabolotska@ukr.net, https://orcid.org/0000-0003-0686-7185

Zamishchak Maria Ihorivna Candidate of Psychological Sciences, Associate Professor of the Department of Psychology, Drohobych Ivan Franko State Pedagogical University, I. Franko St., 24, Drohobych, 27100, tel .: (098) 418-72-43, e-mail: dpszammeri@gmail.com, https://orcid.org/0000-0003-4559-1257

\section{PSYCHOLOGICAL FORMATION FACTORS OF THE PROFESSIONAL "I-CONCEPT" OF FUTURE SPECIALISTS}

Abstract.The article analyzes the I-concept which comprises a set of all the person's ideas about himself including beliefs, assessments and behavior tendencies.

There are two types of the I-concept: positive and negative. It is stated that every person strives for maximum inner harmony. Notions, feelings or ideas contradicting the person's other notions, feelings or ideas lead to disharmony of the personality, to the situation of psychological discomfort.

The professional development of a future specialist was analysed. It is noted that the professional development of a future specialist is a complex, continuous process of "designing" a personality. This mission can be achieved only by the person who possesses a mature personality, who is internally and professionally prepared to do the tasks he has to solve. Personal maturity is expressed by the person's ability to combine, correlate his individual characteristics, status and age capabilities, his own principles with the society and other people's demands.

It is emphasized that a student, as a future professional who tries to achieve a high 
professional culture, needs constant self-analysis, self-awareness of his actions and deeds, self-observation, the ability to have a continuous internal dialogue. Such selfcommunication is the basis of professional self-improvement because it gives the opportunity to correct his own weaknesses, to develop the necessary professional skills and qualities.

It is accentuated that self-esteem is the foundation on which all the person's purposeful activity is built, and which greatly determines its outcome. The future specialist's activity, his participation in professional activity, his needs and ability to assess his own interests depend on the conditions of self-assessment. It is claimed that the future specialist's professionalism requires the formation of his own positive Iconcept. Psychological formation factors of the professional "I-concept" of a future specialist were described. It is stated the positive I-concept basis should include the psychological factors and qualities inherent in the personalities of future specialists.

Keywords: psychological factors, future specialists, I-concept, professional development, professionalization, higher educational establishment.

Постановка проблеми. Швидкий розвиток українського суспільства, його науково-технічної та гуманітарної сфер ставить нові завдання перед системою вищої освіти, передусім, щодо зміни орієнтації професійної підготовки 3 формування професійних знань та вмінь на забезпечення сприятливих умов саме для гармонійного особистісного й професійного розвитку майбутніх фахівців, активізацію їх мотиваційного ресурсу, навчання, самонавчання, розвитку, саморозвитку, виховання, самовиховання, саморегуляції та самоорганізації.

Розвиток Я-концепції має важливе значення саме для особистісного розвитку кожної людини. Обгрунтуємо, яку роль виконує Я-концепція в розвитку особистості майбутнього фахівця, зокрема, з'ясуємо іiі роль у професійному становленні.

Аналіз останніх досліджень і публікацій. В.Юрченко стверджує, що складність дослідження і аналізу феномену Я-концепції у психології полягає, зокрема, саме в існуванні суттєвих розбіжностей у системі понять, що складають iii тезаурус. Існує цілий ряд понять для позначення різних концептів у сфері психології Я, що викликає природні труднощі при їх співставленні.

В Я-концепції запрограмовано, зокрема, якою повинна бути поведінка людини. Я-концепція - це уявлення про Я, яке може бути правильним або спотвореним. Слід зазначити, що вона частково усвідомлена, але частково існує в підсвідомості, усвідомлюючись опосередковано через поведінку.

На думку багатьох психологів, людині притаманне існування стійкої тенденції будувати на основі власних уявлень про себе не тільки свою поведінку, діяльність, але й інтерпретацію власного досвіду. При цьому самосвідомість виступає «в ролі своєрідної призми, завдяки якій заломлюється вся інформація і відбувається розсортовування останньої на найбільш особливу, менш значущу чи зовсім індиферентну для даної конкретної особистості, яка володіє тими чи 
іншими особливостями самосвідомості»[10;11]

Я-концепція в даному випадку виступає як внутрішній фільтр, який визначає саме характер сприймання людиною будь-якої ситуації. Завдяки Я концепції, ситуація осмислюється, отримує значення яке відповідає уявленням людини про себе. Я-концепція вміє прогнозувати сподівання людини, тобто іiі уявлення про те, що повинно статись.

Розрізняють позитивну і негативну Я-концепцію. Хоча в літературі ці поняття схарактеризовані явно недостатньо. Спробуємо все ж таки виділити їх основні риси. Позитивну Я-концепцію можна співставити 3 позитивним ставленням до себе, до самоповаги, прийняття себе, відчуття власної цінності.

Негативна Я-концепція передбачає негативне ставлення до себе, саме неприйняття себе, відчуття власної неповноцінності, песимізм. Притаманно кожній особистості прагнути досягнути максимальної внутрішньої гармонії. Бо Бо саме уявлення, почуття, ідеї, які вступають в суперечність 3 іншими ії уявленнями, почуттями або ідеями спричинюють дисгармонізацію особистості, ситуацію психологічного дискомфорту.

Будь-яка особистість, незалежно від професії, саме при умові позитивного самосприймання почуває себе більш задоволеною, підвищується ії впевненість в собі, продуктивність і ефективність эї діяльності.

Особистості, для яких притаманна негативна Я-концепція, відрізняються високою тривожністю, схильністю до самоприниження і самозаперечення; для них наявні труднощі, пов'язані із спілкуванням, різні соціальні і емоційні проблеми.

Основні положення теорії К.Роджерса ми б сформулювали таким чином:

1. Я-концепція - це система самосприймань. Для особистості та iі поведінки конкретне значення має саме Я-концепція, а не деяке реальне Я.

2. Я-концепція виникає в результаті взаємодії з оточуючим світом, бо саме особливо великий вплив на ії виникнення має соціальний світ.

3. На основі інтерналізації позитивного ставлення до себе зі сторони інших розвивається потреба в позитивному ставленні до себе, чи потреба в самоповазі.

Мета статті виокремити та проаналізувати найбільш важливі та оптимальні психологічні чинники становлення професійної Я-Концепції у майбутніх фахівців.

Виклад основного матеріалу. Професіоналізація у закладі вищої освіти $\epsilon$ процесом саме самоактуалізації особистості в умовах навчально-професійної діяльності та спілкування, що особливо спрямований на максимальну реалізацію власних можливостей та особистісно-професійних якостей. Цей період навчання включає вибір спеціальності із врахуванням власних здібностей.

Термін “професійне становлення особистості" (Є.Борисова, Є.Зеєр, Є.Клімов, 3 Карпенко, М.Савчин та ін.) досить широко використовується у психології $[1 ; 2 ; 16]$. Завдяки псхологічній літературі, професійне становлення 
може бути представлене таким чином: 1) за схемою процесу ( як тимчасова послідовність ступенів, періодів, стадій); 2) за структурою діяльності (як сукупність іï способів і засобів, де саме послідовність їх один за одним має не тимчасову, а цільову детермінацію). Але уявлення про феномен професійний розвиток майбутнього фахівця не зводиться ні до процесуальних, ні до діяльнісних характеристик. Це є їх сукупність, яка пов'язана із особистістю самого майбутнього фахівця.

Професійне становлення майбутнього фахівця - складний, постійний процес “проектування" особистості. Реалізувати цю місію може тільки особистісно зріла людина, яка внутрішньо і професійно підготовлена до вирішення завдань, які стоять перед нею.

Науковець акцентує, що завдання професійного становлення може бути вирішене лише за допомогою реалізації «особистісно орієнтованої педагогіки навчального процесу» [6]. На кожного майбутнього фахівця покладено особливу місію, реалізувати яку він зможе тільки при умові формування особливих особистісних якостей i, зокрема, позитивної Я-концепції.

Науковець зазначає, що розвиток особистості в студентські роки з боку відношення до професійної діяльності так: «юний студент приходить у вуз, вважаючи, що обрана ним з тих чи інших мотивів майбутня професія є бажана для нього; якщо по закінченню вузу в нього буде відчуття, що і він потрібний цій справі, що саме вона стала для нього своєю, то це і буде свідчити про його психологічну особистісну зрілість як спеціаліста»[4]. Тому питання особистісного розвитку студента і формування його готовності до майбутньої професійної діяльності, стверджує науковець - головні в теорії та практиці вдосконалення діяльності сучасного закладу вищої освіти.

Одне із важливих положень теорії особистості полягає в тому, що особистості ведуть себе відповідно до своїх переконань. 3 цього слід зробити висновок, що переконання майбутнього фахівця, які належать до його особистих якостей і властивостей, є вирішальним фактором ефективності його діяльності.

Погоджуючись 3 В.Юрченком [7] про наявність в Я-концепції у майбутнього фахівця елементів, які вказують на прийняття ним соціальнорольових функцій, можуть істотно впливати на процес професійного становлення його як майбутнього фахівця.

Майбутній фахівець повинен реалізувати психологічну підготовку щодо себе для того, щоб потім успішно і якісно працювати 3 іншими людьми. Н.Чепелєва та Л.Уманець [17] пропонують трьохрівневу систему особистісної підготовки майбутніх фахівців у закладі вищої освіти:

- світоглядний - притаманний розвинути професійну свідомість майбутніх фахівців;

- професійний - зорієнтований на оволодіння майбутніми фахівцями необхідною системою знань, вмінь, навичок, компетентностей своєї професійної діяльності; 
Журнал«Герспективитаінноваціїнаукиљ

(Серія«Гедагогіка», Серія «Гецхологія», Серія«Медицин»

№4(4) 2021

- особистісний - сприяє у становленні в майбутніх фахівців професійно значущих якостей, гуманістичної спрямованості, «діалогічності» як центрального ії компонента, здатності до професійної ідентифікації [17].

Н.Чепелєва стверджує, що наявна система підготовки майбутнього фахівця спрямована саме на оволодіння ним теоретичних знань, засвоєння зовнішніх вимог, компетентностей, спеціальних умінь та навичок. Слід зазначити, вміння вибрати адекватну форму прояву своїх емоцій, здатність керувати собою, володіти особистими емоційними станами - показник розвиненої емоційної культури майбутнього фахівця. Все це сприяє повноцінним спілкуванню, взаємодії, діяльності, дає змогу знайти вихід із складних конфліктних ситуацій [17].

Студенту, як майбутньому професіоналу, який прагне досягти високої професійної культури, необхідні постійний самоаналіз, усвідомлення своїх дій та вчинків, самоспостереження, здатність вести безперервний внутрішній діалог. Таке самоспілкування $\epsilon$ основою професійного зростання, самовдосконалення, оскільки дає можливість коригувати особистісні недоліки, розвивати необхідні для професії здібності, якості, компетентності.

Оволодіння своєю професійною діяльністю, як зазначає В.Панок, не може бути зведене до засвоєння інформації та вироблення навичок, а й саме має водночас змінювати внутрішні психічні структури суб' єкта навчання. Для цього психологічні знання повинні мати суб'єктивну значущість для того, зокрема, хто навчається[15]. У більшості досліджень чітко підкреслюється важливість у діяльності майбутнього фахівця рівня його особистісного розвитку, самоактуалізації, професійного зростання. Пропонуються різні шляхи активізації цього процесу: 1) формування спрямованості майбутнього фахівця на оволодіння практичними знаннями, уміннями і навичками, а також психолого-педагогічними знаннями в цілому (С.В.Яремчук); 2) становлення особистісної позиції у процесі освоєння своєї спеціальності (О.Подоланюк, І.Слободянюк); 3) використання активних методів навчання, різноманітних тренінгів, розв'язування психологічних ситуацій, задач, робота 3 інтерактивними методиками (В.Власенко, П.Горностай, Л.Долинська, В.Федорчук, Т.Яценко та ін.); 4) усвідомлення студентами змісту особливостей самоактуалізації особистості майбутніх фахівців та ін.

Науковці стверджують, що оптимальною може бути саме така система підготовки, відбору й атестації кадрів, яка на базі мінімальних стартових вимог створюються умови професійної самоідентифікації студента [14;17]. Під професійною самоідентифікацією, зазначає науковець, розуміється таке оволодіння знаннями, навичками та вміннями, за якими реалізується самодіагностика, самопізнання, застосування до себе тих чи інших вимог професії.

С.Максименко стверджує, що одним із напрямків в особистісній підготовці майбутніх фахівців $\epsilon$ психодіагностичний, який має на увазі можливості 
визначення його особистісно-професійних якостей, здібностей [10]. Проводячи психологічний аналіз впливу різних факторів освітнього процесу на формування професійно значущих якостей майбутнього фахівця, С.Максименко підкреслює, що «вузівська психодіагностика передбачає, насамперед, виявлення, вимірювання та аналіз особистісних якостей фахівця 3 метою розв'язання практичних завдань, спрямованих на корекційну роботу й ефективну організацію процесу формування фахівця».

Зріла самосвідомість характеризується тим, що «в кожному акті усвідомлення світу неминуче бере участь контролююча i керівна влада самосвідомості, від якої людина не вільна навіть тоді, коли вона глибоко занурена в дослідження реального об'єкта» [13]. Але, на жаль, людина може не мати навичок та вмінь у застосуванні потенційних резервів самосвідомості, тобто «цілком свідомо ставитись до фактів зовнішнього світу без самосвідомості, без аналізу про це ставлення» [14]. Таке відволікання, особливо саме в процесі освоєння неоднозначних професійних алгоритмів, веде що найменше до продовження процесу навчання, звички не тільки вчитися, розвиватися, але й працювати «методом проб і помилок», особливо не задумуючись над вдосконаленням себе як суб'єкта діяльності. Тому дана проблема «включення» самосвідомості особистості у професійне навчання там, де в цьому існує необхідність та складає вагоме і важливе завдання дослідницької роботи.

Слід зазначити про провідну роль самооцінки. Більшість дослідників (Б.Ананьєв, Г.Балл, М.Боришевський, А.Ліпкіна, В.Мерлін та ін.), які вивчали роль самооцінки в структурі особистості, зазначають, що саме стійкість та адекватність іï - основа для формування таких рис особистості майбутнього фахівця, як впевненість у собі, почуття власної гідності $[1 ; 2 ; 4]$.

Досліджуючи і аналізуючи феномен самооцінки як чинника, що визначає формування самосвідомості і самопізнання суб`єкта, А.Ліпкіна в своїй праці підкреслює іiі важливу роль в пізнанні людиною не лише себе, але й своїх взаємостосунків 3 іншими людьми і оточуючою дійсністю [8]. Завдяки самосвідомості і самооцінці особистості в процесі діяльності формуються такі важливі якості і особливості, як критичність розуму, самостійність, які дають можливість особистості правильно планувати й реалізувати свою діяльність та свої взаємостосунки з оточуючими.

Вчені акцентують увагу на постійному аналізі і оцінці особистістю власних можливостей, результатів діяльності, своїх особистісних якостей, вчинків i поведінки в цілому, що особливо важливо для майбутніх фахівців [8]. Саме така складна рефлексивна діяльність, тобто постійне переживання й усвідомлення себе, сприяє розвитку самокритичності і пластичності особистості майбутнього фахівця. Але самокритичність, як стверджує науковець, може принести істотну користь лише в тому випадку, коли вона сформована при наявності адекватної самооцінки.

Отже, самооцінка виконує роль підгрунтя, на якому базується вся 
цілеспрямована діяльність особистості, і яке в значній мірі визначає результат цієї діяльності. Ми погоджуємось 3 тим фактом, що від умов самооцінювання залежить активність особистості майбутнього фахівця, їі участь у професійній діяльності, iї прагнення і вміння оцінювати свої інтереси.

Доцільним, на наш погляд, $\epsilon$ теоретичний підхід В.Юрченка щодо становлення Я-концепції майбутнього фахівця [7]. Його дослідження $\epsilon$ підгрунтям наступних наших міркувань: усвідомлення суті психологічної діяльності і іiі особливостей в ході професійного навчання, слід зазначити, що має вести зміни в уявленні про себе як потенційного суб'єкта цієї діяльності. Образ Я уточнюється в процесі професійного становлення особистості майбутнього фахівця. Процес формування особистості майбутнього фахівця $\epsilon$ саме процесом розвитку самосвідомості студента, який може виявлятися в іiі продукті - Я-концепції.

А.Маслоу [12] стверджує, що головною метою освіти є допомога людині в тому, щоб вона стала «настільки хорошою, наскільки вона здатна». Слід зазначити, що одним із засобів досягнення цієї мети стає відкриття цих здібностей, якостей, тобто відкриття себе для себе.

Отже, одним із важливих завдань підготовки майбутніх фахівців має бути особистісна підготовка, яка інтегрує всі інші елементи цієї системи. Саме наголос на особистісному розвиткові студентів лежить в основі сучасного підходу до проблеми формування позитивної Я-концепції. М.Савчин акцентує, що особистість із сильним Я - розумна, мудра, досвідчена, щаслива [16]. Стверджує, що вона ефективно рефлексує та трансцендентує, контролює та моделює свою діяльність та поведінку, володіє свободою та відповідальністю. Їй притаманні стани безпристрасності, безмовності, чесноти. Така особистість, зазначає науковець, поповнює сили в духовній сфері, в такий спосіб долаючи свою слабкість, немочі, духовні, психічні та психологічні травми [16].

Особистість - це цілісна психологічна, соціальна, духовна і моральна структура, яка формується у процесі життя на основі засвоєння нею духовних та моральних ідеалів, суспільних форм свідомості і поведінки.

Професійна придатність не зводиться тільки до рівня академічної підготовки. Зміст підготовки майбутніх фахівців має накладатися на індивідуальні особливості, формувати i розвивати їхні окремі риси, компетентності. Здатність легко встановлювати контакти 3 іншими, бути конструктивними, легкість у спілкуванні, комунікабельність, уміння слухати та підтримувати розмову, емоційна сталість, емпатія мають бути обов’язковою складовою частиною особистості майбутнього фахівця [4;5].

Значущою складовою Я-концепції професіонала $\epsilon$ й емоційна культура. Вміння вибирати адекватну форму прояву своїх емоцій, здатність володіти собою, володіння емоційним інтелектом, керувати своїми емоційними станами показник розвиненої емоційної культури майбутнього фахівця. Все це сприяє повноцінному спілкуванню, дає змогу знайти вихід із складних конфліктних 
ситуацій [7].

Можна виділити наступні психологічні чинники становлення професійної Я-концепції у майбутніх фахівців: автентичність; відкритість власному досвіду; розвиток самопізнання; сила особистості та ідентичність; толерантність до невизначеності; прийняття особистої відповідальності; глибина стосунків 3 іншими людьми; постановка реалістичних цілей; емпатія. Аналізуючи ці психологічні чинники, ми переконуємось, що саме якості, які повинні бути притаманні особистості майбутнього фахівця будуть основою позитивної Яконцепції.

Погоджуючись 3 думкою О.Бондаренко[2], майбутня професійна діяльність вимагає від свого представника перш за все цілком визначеної особистісної праці: відпрацювання власних емоційних і змістових проблем, оволодіння певною культурою самоаналізу та особистісної рефлексії, усвідомлення у більш повному обсязі своїх власних особистісних, моральних, культурних, когнітивних i духовних цінностей. Професіоналізм майбутнього фахівця потребує становлення особистої позитивної Я-концепції. Підсумовуючи вище згадані вимоги до особистості майбутнього фахівця, можна стверджувати, що компетентнісний майбутній фахівець - це перш за все особистісно зріла людина.

Особливе значення, як стверджують науковці, надається розвитку регулятивних механізмів діяльності, поведінки і спілкування, розширенню індивідуальних способів творчого самовираження. Стимулюються пошук самобутнього почерку професійної діяльності, авторство в створенні власних моделей майбутньої діяльності[4;5] .

До структури професійної Я-концепції майбутніх фахівців належать такі компоненти:

1) когнітивний - уявлення особистості про себе як фахівця у професійній діяльності, що виявляються в професійному образі Я - фахівець, професіонал;

2) емоційнооцінний - iї професійна самооцінка і професійне ставлення до себе як компетентного фахівця;

3) поведінковий - саморегуляція i самоконтроль у професійній діяльності[16] .

Висновки. Отож, провідними психологічними чинниками становлення професійної Я концепції майбутніх фахівців є:

1) розвиток здорової особистості, як цілісної психологічної структури, що включає психічний, морально-духовний та соціально-професійний розвиток[5];

2) пізнання себе, своїх (індивідуальних особливостей, темпераменту, характеру, здібностей тощо) на основі рефлексії, ведення особистого щоденника; сприяння усвідомленню майбутніми фахівцями особистісних якостей в процесі професійного становлення, що призводять до формування системи професійно важливих якостей;

3) розвиток особистісної та професійної ідентичності;

4) розвиток у майбутнього фахівця головних здатностей людини; 
Журнал«Герспектвиитаіноовації наукиљ

(Серія«Гедагогіка», Серія«Гцихологія», Серія«Медицинв»

№4(4) 2021

5) розвиток вміння володіння сенсом життя;

6) володіння життєстійкістю саме в складних, кризових, екстремальних, конфліктних ситуаціях та в ситуаціях життєвих випробувань і блокування задоволення основних потреб;

7) розвивати здібності до постійного особистісного зростання, творчі (креативні) здібності як здатність нових способів розв'язання проблем, рефлексивні здібності як раціональне та емоційне осмислення своєї особистості;

8) розвиненість їх професійної свідомості;

9) ставлення студентів до майбутньої професійної діяльності; співвідношення їх реальних уявлень про себе як майбутніх фахівців своєї галузі із ідеальними (еталоном);

10) місце професійної спрямованості у мотиваційній сфері особистості;

11) прагнення професійної самореалізації; значущість для майбутніх фахівців обраної професії, актуальність і значущість професійної самоідентичності;

12) здорова, цілісна особистість викладача закладу вищої освіти;

13) система домінуючих потреб та мотивів ( наміри, інтереси, здібності, ідеал, ціннісні орієнтації, стійка професійна позиція);

14) організація оволодіння основами суб'єктної життєтворчості (оволодіння цінностями i сенсами навчально-професійної діяльності, створення індивідуальних проектів життєвого шляху, фрагментів професійної діяльності, потреба в особистій і професійній самореалізації);

15) організація готовності майбутніх фахівців до самостійної постановки i професійного вирішення теоретико-прикладних завдань, зокрема, проектної культури, що трансформує відношення до власної життєдіяльності і до навчання.

\section{Jimepamypa:}

1.Боднар М. Б. Етнопсихологічні особливості самоактуалізації студентської молоді: монографія - Кременець: ВЦ КОГПІ ім. Тараса Шевченка, 2007. - 196 с.

2.Бондаренко О. Ф. Психологічні особливості сучасної студентської молоді та проблеми професійної підготовки психологів-практиків / Практична психологія та соціальна робота. 2003. - №4. - С. 8-11.

3.Боришевський М. Й. Психологічні механізми розвитку особистості вимірах Педагогіка і психологія. - 1996. - № 3. - С. 26-33.

4. Заболоцька С.І., Кулик В.Б. Формування відповідального ставлення до професійної ролі майбутніх педагогів. Теорія і практика сучасної психології : зб. наук. пр. / Класич. приват. ун-т. - Запоріжжя, 2019. - №6, т.2. С.50-53.

5.Заміщак М.I. Показники ефективності психологічного супроводу особистісного розвитку майбутнього педагога. Матеріали Міжнародної науково-практичної конференції "Тенденції та перспективи розвитку науки і освіти в умовах глобалізації": Зб. наук. праць. Переяслав - Хмельницький, 2019. - Вип. 45. С.259 - 261.

6.Кон И.С. В поисках себя: Личность и её самосознание. - М.: Политиздат, 1984. - 335 с.

7. Кузикова С.Б. Коррекция Я-концепции как условие преодоления конфликтности у подростков / Сумской гос. пед. ин-т им. А.С.Макаренко. - Сумы, 1999. - 28 с. 
8. Липкина А.И., Рыбак Л.А. Критичность и самооценка в учебной деятельности. - М.: Педагогика, 1968. - 142 с.

9.Лисина М.И. Общение, личность и психика ребёнка: Изб. психол. труды в 70 т. / Под ред. А.Г.Рузской. - М.: Воронеж, 1997. - 384 с.

10.Максименко С. Д. Розвиток психіки в онтогенезі : [В 2 т.]. - К. : Форум, 2002. - Т. 2. Моделювання психологічних новоутворень: генетичний аспект. -335 с.

11.. Максименко С. Особистість: прогноз розвитку і життєвий шлях. Психолог. 2006. - №7 (199). - C. 5-11.

12.Маслоу А. Самоактуализация // Психология личности: тексты / Под ред. Ю.Б.Гиппенрейтер, А.А.Пузырея. - М.: Изд-во МГУ, 1982. - с.108-118.

13.Мясоид П.А. Теория и практика в работе школьного психолога // Вопросы психологии. - 1993. - №4. - С. 73-79.

14.Оборина Д.В. Об особенностях ментальности будущих педагогов и психологов // Вестник МГУ, серия №14 «Психология». - 1994. - №2. - С. 41-49.

15. Панок В.Г. Концептуальні підходи до формування особистості практикуючого психолога // Практична психологія та соціальна робота. - 1998. - №4. - С. 5-7, №5. - С. 4-6.

16.Савчин М.В. Теоретико-методологічні засади створення та реалізації програми особистісно-професійного розвитку майбутнього педагога. Особистісно - професійний розвиток майбутнього педагога: монографія / За ред.проф. М.В.Савчина. - Дрогобич: ВВДДПУ ім. І.Франка, 2014. С.9-18.

17.Чепелева Н.В., Уманец Л.И. Проблемы личностной подготовки психологов-практиков в условиях вуза // Сборник материалов междунар. конф. "Актуальные проблемы психологической службы: теория и практика”. - Том 2. - Одесса. - 1992. - С.111-112.

\section{References:}

1.Bodnar, M. B. (2007). Etnopsihologichni osoblivosti samoaktualizacï students'koï molodi [Ethnopsychological features of self-actualization of student youth]. Kremenec': VC KOGPI im. Tarasa Shevchenka [in Ukrainian].

2.Bondarenko, O. F. (2003). Psihologichni osoblivosti suchasnoï students'koï molodi ta problemi profesijnoï pidgotovki psihologiv-praktikiv [Psychological features of modern student youth and problems of professional training of psychologists-practitioners]. Praktichna psihologija ta social'na robota - Practical psychology and social work, 4, 8-11 [in Ukrainian].

3. Borishevs'kij, M. J. (1996). Psihologichni mehanizmi rozvitku osobistosti vimirah [Psychological mechanisms of personality development in the dimensions]. Pedagogika i psihologija - Pedagogy and Psychology, 3, 26-33 [in Ukrainian].

4. Zaboloc'ka, S.I., Kulik, V.B. (2019). Formuvannja vidpovidal'nogo stavlennja do profesijnoï roli majbutnih pedagogiv[Formation of a responsible attitude to the professional role of future teachers]. Teorija i praktika suchasnoï psihologï - Theory and practice of modern psychology, 6, S.50-53 [in Ukrainian].

5. Zamishhak,(2019). M.I. Pokazniki efektivnosti psihologichnogo suprovodu osobistisnogo rozvitku majbutn'ogo pedagoga [Indicators of the effectiveness of psychological support of personal development of the future teacher]. Tendencii ta perspektivi rozvitku nauki i osviti $v$ umovah globalizacii - Trends and prospects for the development of science and education in the context of globalization, 45, 259 - 261 [in Ukrainian].

6. Kon, I.S. (1984). V poiskah sebja: Lichnost' $i$ ejo samosoznanie [In search of self: Personality and its self-consciousness]. M.: Politizdat [in Russian].

7. Kuzikova, S.B. (1999). Korrekcija Ja-koncepcii kak uslovie preodolenija konfliktnosti u podrostkov [Correction of self-concept as a condition for overcoming conflict in adolescents]. Sumskoj gos. ped. in-t im. A.S.Makarenko: Sumy [in Ukrainian]. 
8. Lipkina, A.I., Rybak, L.A. (1968). Kritichnost' $i$ samoocenka v uchebnoj dejatel'nosti [Criticality and self-esteem in educational activities]. M.: Pedagogika [in Russian].

9. Lisina, M.I. (1997). Obshhenie, lichnost' i psihika rebjonka [Communication, personality and psyche of the child]. M.: Voronezh [in Russian].

10. Maksimenko, S. D. (2002). Rozvitok psihiki v ontogenezi [Development of the psyche in ontogenesis]. K. : Forum [in Ukrainian].

11.. Maksimenko, S. (2006). Osobistist': prognoz rozvitku i zhittevij shljah [Personality: development forecast and life path]. Psiholog - Psychologist, 7 (199), 5-11 [in Ukrainian].

12. Maslou, A. (1982). Samoaktualizacija [Self-actualization]. M.: Izd-vo MGU[in Russian].

13. Mjasoid, P.A. (1993). Teorija i praktika v rabote shkol'nogo psihologa [Theory and practice in the work of a school psychologist]. Voprosy psihologii - Questions of psychology, 4, 73-79 [in Russian].

14. Oborina D.V.(1994). Ob osobennostjah mental'nosti budushhih pedagogov i psihologov [On the peculiarities of the mentality of future teachers and psychologists]. Vestnik MGU, serija №14 «Psihologija»-MSU Bulletin, series №14 "Psychology", 2, 41-49 [in Russian].

15. Panok, V.G. (1998). Konceptual'ni pidhodi do formuvannja osobistosti praktikujuchogo psihologa [Conceptual approaches to the formation of the personality of a practicing psychologist]. Praktichna psihologija ta social'na robota. - Practical psychology and social work, 5, 4-6 [in Ukrainian].

16. Savchin, M.V. (2014). Teoretiko-metodologichni zasadi stvorennja ta realizaciö programi osobistisno-profesijnogo rozvitku majbutn'ogo pedagoga. Osobistisno - profesijnij rozvitok majbutn'ogo pedagoga: monografija [heoretical and methodological principles of creating and implementing a program of personal and professional development of the future teacher. Personally professional development of the future teacher]. Drogobich: VVDDPU im. I.Franka [in Ukrainian].

17. Chepeleva, N.V., Umanec, L.I. (1992). Problemy lichnostnoj podgotovki psihologovpraktikov $\mathrm{v}$ uslovijah vuza [Problems of personal training of psychologists-practitioners in the conditions of high school]. Sbornik materialov mezhdunar. konf. "Aktual'nye problemy psihologicheskoj sluzhby: teorija i praktika". - Collection of international materials. conf. "Current issues of psychological service: theory and practice.", 2, 111-112 [in Russian]. 